\title{
Flutamide: Impact of Consciousness Energy Healing Treatment on the Physicochemical and Thermal Characteristics
}

\author{
Gopal Nayak ${ }^{1}$, Mahendra Kumar Trivedi ${ }^{1}$, Alice Branton ${ }^{1}$, Dahryn Trivedi ${ }^{1}$ and \\ Snehasis Jana ${ }^{2 *}$
}

ISSN: 2576-9170

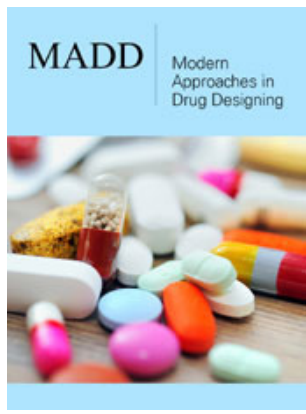

*Corresponding author: Snehasis Jana, Trivedi Science Research Laboratory Pvt. Ltd., Bhopal, India

Submission: 琒January 03, 2019

Published: 㔊 March 14, 2019

Volume 2 - Issue 4

How to cite this article: Gopal N, Mahendra $\mathrm{K}$ T, Alice B, Dahryn $\mathrm{T}$ Snehasis J. Flutamide: Impact of Consciousness Energy Healing Treatment on the Physicochemical and Thermal Characteristics. Mod Appro Drug Des.2(4). MADD.000542.2019.

DOI: 10.31031/MADD.2019.02.000542.

Copyright@ Gopal Nayak, This article is distributed under the terms of the Creative Commons Attribution 4.0 International License, which permits unrestricted use and redistribution provided that the original author and source are credited.
${ }^{1}$ Trivedi Global, Inc., Henderson, USA

${ }^{2}$ Trivedi Science Research Laboratory Pvt. Ltd., India

\begin{abstract}
Flutamide is a toluidine derivative that acts as an antiandrogen and binds to the androgen receptor, thereby inhibits the action of testosterone. This study was done on flutamide to analyze the outcome of the Trivedi Effect ${ }^{\circledR}$-Consciousness Energy Healing Treatment on its various physicochemical and thermal properties. For this, the sample was divided into two parts and named as the control and treated sample. No treatment was given to the control part, while the treated part was received the Trivedi Effect ${ }^{\circledR}$-Biofield Energy Healing Treatment, remotely by a renowned Biofield Energy Healer, Gopal Nayak. The experimental results revealed the significant reduction in the particle size values by $3.35 \%$ $\left(\mathrm{d}_{10}\right), 4.95 \%\left(\mathrm{~d}_{50}\right), 10.75 \%\left(\mathrm{~d}_{90}\right)$, and $8.91 \%\{\mathrm{D}(4,3)\}$; thereby, the specific surface area was increased by $5.32 \%$ in the treated sample compared to the control sample. The powder XRD peak intensities and crystallite sizes were significantly altered in the in the range from $-50.66 \%$ to $30.17 \%$ and $-50.56 \%$ to $86.54 \%$, respectively; thus, the average crystallite size was significantly reduced by $11.82 \%$ in the treated flutamide compared with the control sample. The residue weight was reduced in the treated sample by $19.88 \%$; whereas, the maximum thermal degradation temperature was decreased by $2.38 \%$ in the treated flutamide compared to the control sample. The latent heat of fusion of the treated flutamide was significantly increased by $9.84 \%$ compared to the control sample. The overall results indicated the significant change in the particle size, crystal properties, and thermal stability of the treated sample after the Biofield Energy Treatment as compared to the untreated sample, which might be due to the possible formation of a novel polymorph. Hence, the Biofield Energy treated flutamide sample might help in developing its pharmaceutical formulation with improved solubility, absorption, and bioavailability that might improve its performance against various diseases, i.e., prostate cancer, androgen-dependent skin and hair conditions including acne, seborrhea, hirsutism, and scalp hair loss, hyperandrogenism, as well useful for feminizing hormone therapy aimed at transgender women.
\end{abstract}

Keywords: Complementary and Alternative Medicine, Flutamide, The Trivedi Effect ${ }^{\circledast}$, Energy of Consciousness Healing Treatment, PSA, PXRD, TGA, DSC

\section{Introduction}

Flutamide belongs to a category of non-steroidal anti-androgen. It binds to the androgen receptor and blocks the action of testosterone thereby elevates the plasma testosterone and estradiol $[1,2]$. It is used in the treatment of prostatic carcinoma in combination with a GnRH agonist due to its property to compete for the testosterone receptor binding sites in the prostate cells and may prevent the "tumor flare" phenomenon related to the GnRH agonists. The mechanism of action of flutamide is based on its structural similarity with testosterone, thus it binds to the receptors itself and prevents the attachment as well as the action of testosterone on the prostate cancer cells. Therefore, the cancer cells stop growth in the lack of testosterone and their death occurs $[3,4]$. The other uses of flutamide involve the treatment of excessive hair growth, acne, and high androgen levels in women [5]. However, it may cause some adverse reactions such as hot flashes, diarrhea, gynecomastia, and decreased libido [6]. Flutamide is administered through oral route preferably and its absorption, distribution, and excretion are very rapid. However, it is $95 \%$ plasma protein-bound and rapidly metabolized to various compounds. The biological half-life of its alpha-hydroxylated metabolite is 
approximately 6 hours and $95 \%$ of the dose is observed to be excreted by the kidneys $[7,8]$.

The absorption, bioavailability, and efficacy of a drug are affected by its physicochemical properties, which also decide its biological profile $[8,9]$. Thus, various researches were done in recent days to improve the efficacy and bioavailability of the drug by altering the physiochemical properties such as such as particle size, surface area, crystal properties, melting point, etc. $[10,11]$. Biofield Energy Healing is considered nowadays as an integrated healthcare approach under the field of Complementary and Alternative Medicine (CAM) therapies and proved beneficial against various health conditions $[12,13]$. Various types of Energy Healing therapies are accepted by most of the U.S. population and hence, the National Institutes of Health (NIH) included them under the CAM category $[14,15]$. In this scenario, the Trivedi Effect $^{\circledR}$-Consciousness Energy Healing Treatment has also been found to have a remarkable effect on the living organisms and non-living materials. The Biofield Energy Healing Treatment (the Trivedi Effect $^{\circledR}$ ) has been reported in various scientific studies regarding its significant outcome in the field of agriculture science $[16,17]$, biotechnology [18], microbiology [19-21], skin health [22], livestock [23], cancer [24,25], and altering the properties of various pharmaceutical/nutraceutical compounds [26-28], and metals, ceramics, and polymers [29,30]. Hence, this study was designed to analyze the impact of the Biofield Energy Treatment on the physicochemical and thermal properties of flutamide with the help of analytical techniques such as, particle size analysis (PSA), powder X-ray diffraction (PXRD), thermogravimetric analysis (TGA), and differential scanning calorimetry (DSC).

\section{Materials and Methods}

\section{Chemicals and reagents}

Flutamide was purchased from Tokyo Chemical Industry Co. Ltd, Japan; whereas, the other chemicals used during the experiments were purchased from India.

\section{Consciousness energy healing treatment strategies}

The test compound flutamide was first divided into two parts. One part among them was denoted as a control sample and it did not receive any Biofield Energy Treatment; but, was subjected to a "sham" healer under the similar laboratory conditions, who did not have any knowledge about the Biofield Energy Healing Treatment. Besides, the second part of the sample was considered

control sample. Table 1: Particle size distribution of the control and Biofield Energy Treated flutamide.

\begin{tabular}{|c|c|c|c|c|c|}
\hline Parameter & $\mathbf{d}_{\mathbf{1 0}}(\boldsymbol{\mu m})$ & $\mathbf{d}_{\mathbf{5 0}}(\boldsymbol{\mu m})$ & $\mathbf{d}_{\mathbf{9 0}}(\boldsymbol{\mu m})$ & $\mathbf{D}(\mathbf{4 , 3})(\boldsymbol{\mu m})$ & $\mathbf{S S A}\left(\mathbf{m}^{2} / \mathbf{g}\right)$ \\
\hline Control & 50.43 & 204.2 & 694.72 & 298.04 & 0.094 \\
\hline Biofield Treated & 48.74 & 194.1 & 620.01 & 271.47 & 0.099 \\
\hline Percent change (\%) & -3.35 & -4.95 & -10.75 & -8.91 & 5.32 \\
\hline
\end{tabular}

$\mathrm{d}_{10}, \mathrm{~d}_{50}$ and $\mathrm{d}_{90}$ : particle diameter corresponding to $10 \%, 50 \%$, and $90 \%$ of the cumulative distribution, $\mathrm{D}(4,3)$ : the average mass-volume diameter, and SSA: the specific surface area.

The particle size distribution of a drug may have a huge impact on its solubility and dissolution parameters that further plays a significant role in the absorption and bioavailability profile of the as the Biofield Energy Treated sample, which received the Trivedi Effect ${ }^{\circledR}$-Consciousness Energy Healing Treatment by the renowned Biofield Energy Healer, Gopal Nayak (India) remotely for 3 minutes. This Biofield Energy Treatment was provided through the healer's unique energy transmission process. Consequently, the control and the Biofield Energy Treated flutamide samples were kept in similar sealed conditions and further characterized with the help of sophisticated analytical techniques.

\section{Characterization}

The PSA, PXRD, TGA/DTG, and DSC, analysis of flutamide were performed. The PSA was performed with the help of Malvern Mastersizer 2000 (UK) using the wet method [31,32]. Similarly, the powder XRD analysis of flutamide powder sample was performed with the help of Rigaku MiniFlex-II Desktop X-ray diffractometer (Japan) [33,34]. The average size of crystallites was calculated from the powder XRD data using the Scherrer's formula (1):

$$
G=k \lambda / \beta \cos \theta
$$

Where $\mathrm{G}$ is the crystallite size in $\mathrm{nm}, \mathrm{k}$ is the equipment constant, $\lambda$ is the radiation wavelength, $\beta$ is the full width at half maximum, and $\theta$ is the Bragg angle [35].

Similarly, the TGA/DTG thermograms of flutamide were obtained with the help of TGA Q50 TA instruments [31,32]. The DSC analysis of flutamide was performed with the help of DSC Q200, TA Instruments. The \% change in particle size, specific surface area (SSA), peak intensity, crystallite size, melting point, latent heat, weight loss and the maximum thermal degradation temperature $\left(\mathrm{T}_{\max }\right)$ of the treated flutamide was calculated compared with the control sample using the following equation 2 :

$$
\% \text { change }=\frac{[\text { Treated }- \text { Control }]}{\text { Control }} \times 100
$$

\section{Resullt and Discussion}

\section{Particle Size Analysis (PSA)}

The particle size analysis of the control and treated flutamide samples was done and mentioned in Table 1 . The treated sample showed particle size distribution at $\mathrm{d}_{10}, \mathrm{~d}_{50}, \mathrm{~d}_{90}$, and D $(4,3)$ was reduced by $3.35 \%, 4.95 \%, 10.75 \%$, and $8.91 \%$, respectively, compared to the particle size distribution of the control sample. Moreover, the Biofield Energy Treated sample also showed an increase in the specific surface area by $5.32 \%$ in comparison to the

drug $[36,37]$. Moreover, the reduced particle sizes contribute to the increased surface area of drug, which helps in improving its solubility. Thus, it is anticipated that the treated sample might show 
better solubility, absorption, and bioavailability after the Biofield Energy Treatment, compared to the control sample.

\section{Powder X-ray diffraction (PXRD) analysis}

The PXRD diffractograms of the control and treated samples are given in Figure 1 that showed the presence of intense and sharp peaks in the diffractograms, thereby indicated the crystalline nature of both the samples. The further analysis was done for the comparative study of the relative peak intensities, and crystallite size among the control and the treated sample and data was presented in Table 2. The peak intensities of the diffraction peaks of the treated flutamide sample were significantly altered in the range from $-50.66 \%$ to $30.17 \%$ compared to the control sample that might indicate the altered crystallinity of the sample after the Biofield Energy Treatment in comparison to the untreated sample. The treated sample also showed alterations in the crystallite sizes corresponding to the characteristic peaks in the range from $-50.56 \%$ to $86.54 \%$ compared with the control sample. The average crystallite size of the treated flutamide sample $(158.66 \mathrm{~nm})$ was also found to be decreased by $11.82 \%$ compared to the control sample $(179.92 \mathrm{~nm})$.
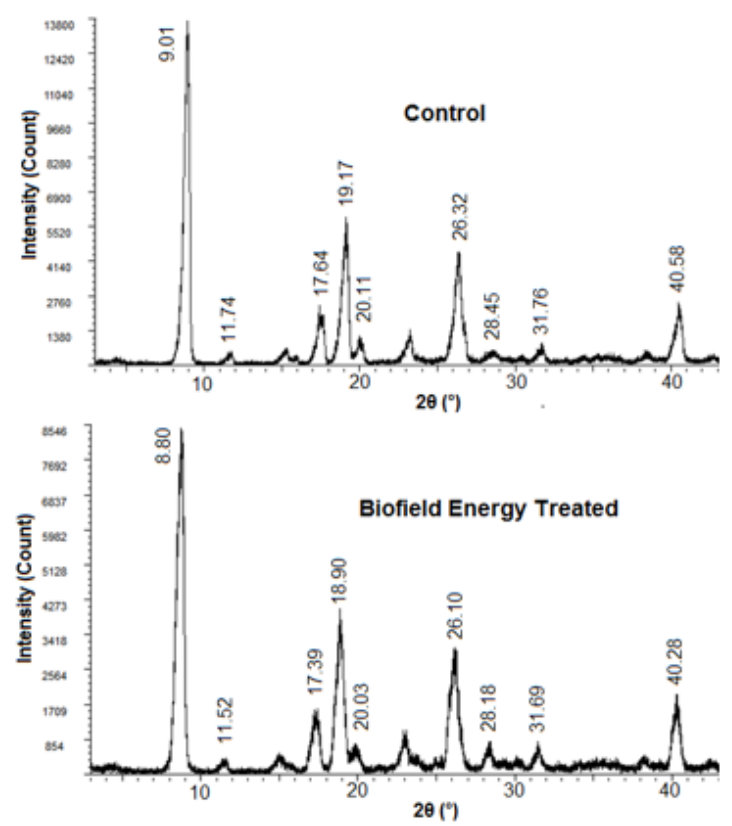

Figure 1: PXRD diffractograms of the control and biofield energy treated flutamide.

Table 2: PXRD data for the control and biofield energy treated flutamide.

\begin{tabular}{|c|c|c|c|c|c|c|c|c|}
\hline \multirow{2}{*}{ Entry No. } & \multicolumn{2}{|c|}{ Bragg angle $\left({ }^{\circ} 2 \theta\right)$} & \multicolumn{3}{|c|}{ Intensity (cps) } & \multicolumn{3}{|c|}{ Crystallite size (G, nm) } \\
\hline & Control & Treated & Control & Treated & $\%$ change & Control & Treated & $\%$ change \\
\hline 1 & 9.01 & 8.8 & 2952 & 3092 & 4.74 & 234 & 157.8 & -32.56 \\
\hline 2 & 11.74 & 11.52 & 105 & 88 & -16.19 & 214 & 192 & -10.28 \\
\hline 3 & 17.64 & 17.39 & 401 & 522 & 30.17 & 261 & 164 & -37.16 \\
\hline 4 & 19.17 & 18.9 & 1930 & 1422 & -26.32 & 168.2 & 159 & -5.47 \\
\hline 5 & 20.11 & 20.03 & 302 & 149 & -50.66 & 162 & 161 & -0.62 \\
\hline 6 & 26.32 & 26.1 & 1720 & 1173 & -31.8 & 135.1 & 136.1 & 0.74 \\
\hline 7 & 28.45 & 28.18 & 176 & 203 & 15.34 & 104 & 194 & 86.54 \\
\hline 8 & 31.76 & 31.69 & 164 & 123 & -25 & 178 & 88 & -50.56 \\
\hline 9 & 40.58 & 40.28 & 770 & 573 & -25.58 & 163 & 176 & 7.98 \\
\hline
\end{tabular}

The altered peak intensity and crystallite sizes of the crystalline compound are indicative of the altered crystal morphology [38]. Also, the changes in the PXRD pattern might indicate the formation of a new polymorph of the flutamide sample, which may help in improving the drug performance during the product development $[39,40]$. Hence, it is presumed that there might be a polymorphic transition of flutamide that takes place due to the Biofield Energy Treatment, which might ensure its better performance as compared to the control sample.

\section{Thermal gravimetric analysis (TGA)/Differential ther- mogravimetric analysis (DTG)}

The TG analysis revealed the thermal degradation pattern of both, the control and the treated sample (Figure 2). The thermal analysis results revealed that the treated sample showed $0.33 \%$ more weight loss during the thermal heating. However, the residue weight was significantly reduced by $19.88 \%$ as compared to the control sample (Table 3). The reduced residue quantity and more 
weight loss during the heating process indicated that the thermal stability of the biofield energy treated flutamide was reduced compared to the control sample.
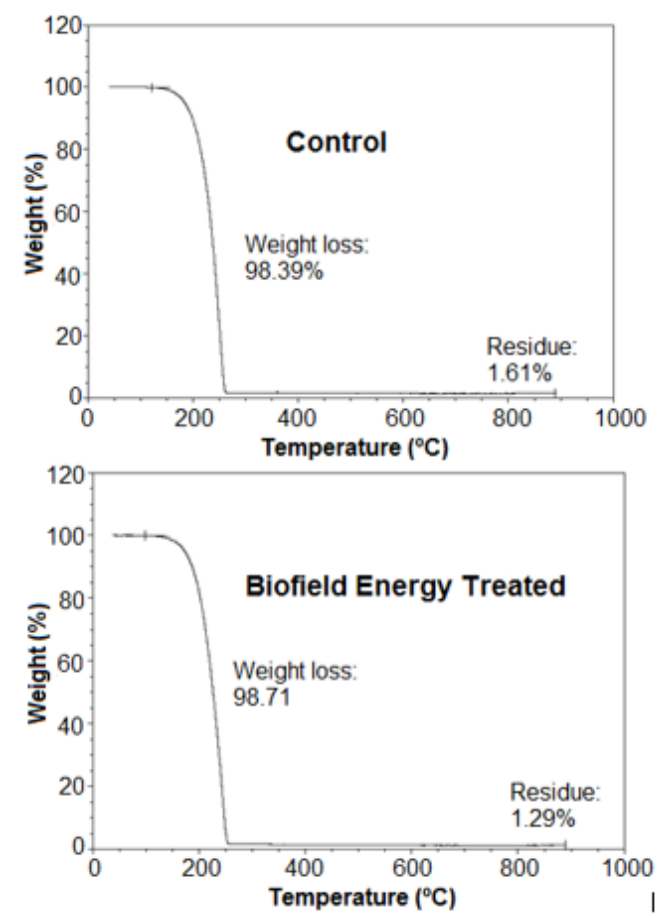

Figure 2: TGA thermograms of the control and biofield energy treated flutamide.
Besides, the DTG thermograms of both the samples showed a single peak (Figure 3). The maximum thermal degradation temperature $\left(\mathrm{T}_{\max }\right)$ was analysed from the thermogram that showed $2.38 \%$ reduction in the $\mathrm{T}_{\max }$ of the treated sample as compared to the control flutamide sample (Table 3). The TGA/DTG data indicated the increased thermal degradation of the treated sample after the Biofield Energy Treatment compared to the untreated sample, which might occur due to the reduction in the particle size of the treated flutamide sample [41].

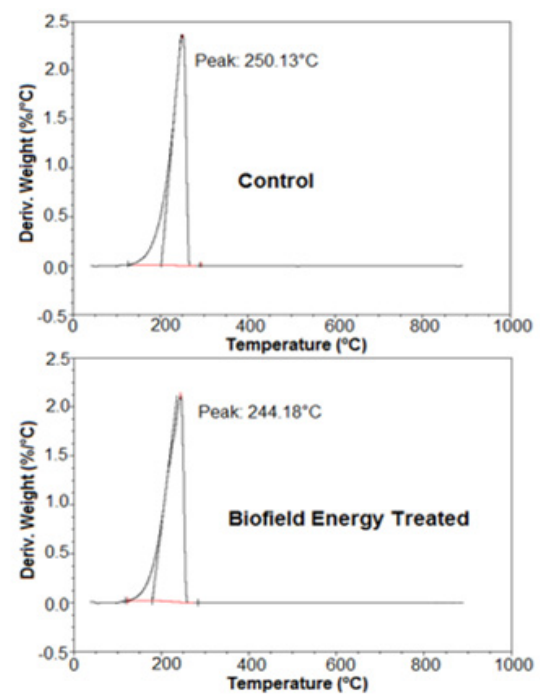

Figure 3: DTG thermograms of the control and biofield energy treated flutamide.

Table 3: TGA/DTG data of the control and biofield energy treated samples of flutamide.

\begin{tabular}{|c|c|c|c|}
\hline \multirow{2}{*}{ Sample } & \multicolumn{2}{|c|}{ TGA } & DTG \\
\cline { 2 - 4 } & Total weight loss (\%) & Residue \% & T T $_{\max }\left({ }^{\circ} \mathrm{C}\right)$ \\
\hline Control & 98.39 & 1.61 & 250.13 \\
\hline Biofield Energy Treated & 98.71 & 1.29 & 244.18 \\
\hline \% Change & 0.33 & -19.88 & -2.38 \\
\hline
\end{tabular}

\section{Differential scanning calorimetry (DSC) analysis}

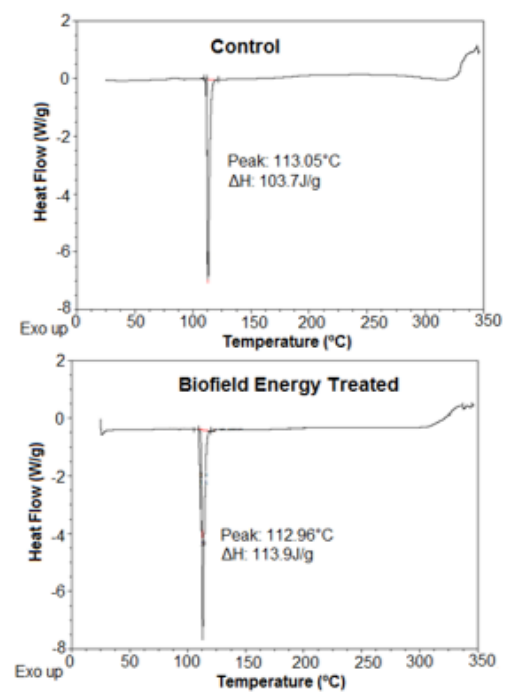

Figure 4: DSC thermograms of the control and biofield energy treated flutamide. 
Table 4: DSC data for the control and biofield energy treated samples of flutamide.

\begin{tabular}{|c|c|c|}
\hline Sample & Melting point $\left({ }^{\circ} \mathbf{C}\right)$ & $\Delta \mathbf{H}(\mathbf{J} / \mathbf{g})$ \\
\hline Control Sample & 113.05 & 103.7 \\
\hline Biofield Energy Treated & 112.96 & 113.9 \\
\hline \% Change & -0.08 & 9.84 \\
\hline
\end{tabular}

The DSC thermograms of the control and the treated flutamide samples were shown in Figure 4 that revealed the presence of a single peak in both the thermograms. This sharp endothermic peak was considered as the melting peak of the control and the treated sample. The further analysis showed the slight decrease $(0.08 \%)$ in the melting temperature of the treated sample; however, the latent heat of fusion $(\Delta \mathrm{H})$ was significantly increased by $9.84 \%$ as compared to the control sample (Table 4). The altered melting temperature and $\Delta \mathrm{H}$ of the treated sample might result due to some changes in the particle size, molecular chain and the crystal structure of the flutamide [41,37] after the Biofield Energy Treatment.

\section{Conclusion}

The study indicated the significant impact of the Trivedi Effect ${ }^{\circledR}$ Consciousness Energy Healing Treatment on the physicochemical properties of flutamide. The particle size data revealed a significant decrease in the particle size of the Biofield Energy Treated sample at $\mathrm{d}_{10}, \mathrm{~d}_{50}, \mathrm{~d}_{90}$ and $\mathrm{D}(4,3)$ by $3.35 \%, 4.95 \%, 10.75 \%$, and $8.91 \%$, respectively in comparison to the control sample. The effect of the reduced particle size of the Biofield Energy Treated sample was also visible on the specific surface area that was observed to be increased by $5.32 \%$ compared with the untreated sample. The powder XRD peak intensities and crystallite sizes were significantly altered in the in the range from $-50.66 \%$ to $30.17 \%$ and $-50.56 \%$ to $86.54 \%$, respectively; thus, the average crystallite size was significantly reduced by $11.82 \%$ in the treated flutamide compared with the control sample. The residue weight was reduced in the treated sample by $19.88 \%$; whereas, the maximum thermal degradation temperature was decreased by $2.38 \%$ in the treated flutamide compared to the control sample. The latent heat of fusion of the treated flutamide was significantly increased by $9.84 \%$ compared to the control sample. Thus, the overall results concluded that the Trivedi Effect ${ }^{\circledR}$-Consciousness Energy Healing Treatment has a significant effect on the flutamide that might help in forming a novel polymorph of it with improved solubility, absorption, and bioavailability and altered thermal stability as compared to the control sample. Hence, the Biofield Energy Treated flutamide sample might be more beneficial to be used during formulation development by providing better bioavailability and efficacy against various diseases, i.e., prostate cancer, androgen-dependent skin and hair conditions including acne, seborrhea, hirsutism, and scalp hair loss, hyperandrogenism, as well useful for feminizing hormone therapy aimed at transgender women.

\section{References}

1. Galbraith SM, Duchesne DM (1997) Androgens and prostate cancer: biology, pathology and hormonal therapy. European Journal of Cancer 33(4): 545-554.
2. Sufrin G, Coffey DS (1976) Flutamide. Mechanism of action of a new nonsteroidal antiandrogen. Invest Urol 13(6): 429-434.

3. Labrie F, Dupont A, Giguère M, Borsanyi JP, Lacourciere Y, et al. (1988) Combination therapy with flutamide and castration (orchiectomy or LHRH agonist): The minimal endocrine therapy in both untreated and previously treated patients with advanced prostate cancer. Prog Clin Biol Res 260: 41-62.

4. Labrie F (1993) Mechanism of action and pure antiandrogenic properties of flutamide. Cancer 72(12 Suppl): 3816-3827.

5. Sachdeva S (2010) Hirsutism: evaluation and treatment. Indian J Dermatol 55(1): 3-7.

6. Kumar RJ, Barqawi A, Crawford ED (2005) Adverse events associated with hormonal therapy for prostate cancer. Rev Urol 7: S37-S43.

7. Marchetti B, Labrie F (1988) Characteristics of flutamide action on prostatic and testicular functions in the rat. J Steroid Biochem 29(6): 691-698.

8. Miranda A, Caraballo I, Millán M (2002) Stability study of flutamide in solid state and in aqueous solution. Drug Dev Ind Pharm 28(4): 413-422.

9. Anjum S, Swan SK, Lambrecht LJ, Radwanski E, Cutler DL, et al. (1999) Pharmacokinetics of flutamide in patients with renal insufficiency. Br J Clin Pharmacol 47(1): 43-47.

10. Savjani KT, Gajjar AK, Savjani JK (2012) Drug solubility: importance and enhancement techniques. ISRN Pharm 195727.

11. Khadka P, Ro J, Kim H, Kim I, Kim JT, et al. (2014) Pharmaceutical particle technologies: an approach to improve drug solubility, dissolution and bioavailability. Asian J Pharm 9(6): 304-316.

12. Frass M, Strassl RP, Friehs H, Müllner M, Kundi M, et al. (2012) Use and acceptance of complementary and alternative medicine among the general population and medical personnel: a systematic review. Ochsner J 12(1): 45-56.

13. Barnes PM, Bloom B, Nahin RL (2008) Complementary and alternative medicine use among adults and children: United States, 2007. Natl Health Stat Report 12: 1-23.

14. Rubik B (2002) The biofield hypothesis: Its biophysical basis and role in medicine. J Altern Complement Med 8(6): 703-717.

15. Koithan M (2009) Introducing complementary and alternative therapies. J Nurse Pract 5(1): 18-20.

16. Trivedi MK, Branton A, Trivedi D, Nayak G, Mondal SC, et al. (2015) Morphological characterization, quality, yield and DNA fingerprinting of biofield energy treated alphonso mango (Mangifera indica L). Journal of Food and Nutrition Sciences 3(6): 245-250.

17. Trivedi MK, Branton A, Trivedi D, Nayak G, Mondal SC, et al. (2015) Evaluation of biochemical marker-glutathione and DNA fingerprinting of biofield energy treated Oryza sativa. American Journal of Bio Science 3(6): 243-248.

18. Nayak G, Altekar N (2015) Effect of biofield treatment on plant growth and adaptation. J Environ Health Sci 1(2): 1-9.

19. Trivedi MK, Patil S, Shettigar H, Mondal SC, Jana S (2015) Evaluation of biofield modality on viral load of Hepatitis B and C viruses. J Antivir Antiretrovir 7: 083-088.

20. Trivedi MK, Patil S, Shettigar H, Mondal SC, Jana S (2015) An impact of biofield treatment: Antimycobacterial susceptibility potential using BACTEC 460/MGIT-TB System. Mycobact Dis 5: 189.

21. Trivedi MK, Branton A, Trivedi D, Nayak G, Charan S, et al. (2015) Phenotyping and 16S rDNA analysis after biofield treatment on Citrobacter braakii: A urinary pathogen. J Clin Med Genom 3(1): 129.

22. Kinney JP, Trivedi MK, Branton A, Trivedi D, Nayak G, et al. (2017) Overall skin health potential of the biofield energy healing based herbomineral formulation using various skin parameters. American Journal of Life Sciences 5(2): 65-74. 
23. Trivedi MK, Branton A, Trivedi D, Nayak G, Mondal SC, (2015) Effect of biofield treated energized water on the growth and health status in chicken (Gallus gallus domesticus). Poultry, Fisheries \& Wildlife Sciences 3(2): 140.

24. Trivedi MK, Patil S, Shettigar H, Mondal SC, Jana S (2015) The potential impact of biofield treatment on human brain tumor cells: A time-lapse video microscopy. J Integr Oncol 4(3): 141.

25. Trivedi MK, Patil S, Shettigar H, Gangwar M, Jana S (2015) In vitro evaluation of biofield treatment on cancer biomarkers involved in endometrial and prostate cancer cell lines. J Cancer Sci Ther 7(7): 253257.

26. Trivedi MK, Branton A, Trivedi D, Nayak G, Nykvist CD, et al. (2017) Evaluation of the Trivedi Effect ${ }^{\circledR}$ - Energy of Consciousness Energy Healing Treatment on the physical, spectral, and thermal properties of zinc chloride. American Journal of Life Sciences 5(1): 11-20.

27. Trivedi MK, Patil S, Shettigar H, Bairwa K, Jana S (2015) Spectroscopic characterization of biofield treated metronidazole and tinidazole. Med chem 5: 340-344.

28. Trivedi MK, Branton A, Trivedi D, Shettigar H, Bairwa K, et al. (2015) Fourier transform infrared and ultraviolet-visible spectroscopic characterization of biofield treated salicylic acid and sparfloxacin. Nat Prod Chem Res 3: 186.

29. Trivedi MK, Tallapragada RM, Branton A, Trivedi D, Nayak G, et al. (2015) The potential impact of biofield energy treatment on the physical and thermal properties of silver oxide powder. International Journal of Biomedical Science and Engineering 3(5): 62-68.

30. Trivedi MK, Tallapragada RM, Branton A, Trivedi D, Nayak G, et al. (2015) Analysis of physical, thermal, and structural properties of biofield energy treated molybdenum dioxide. International Journal of Materials Science and Applications 4(5): 354-359.

31. Trivedi MK, Sethi KK, Panda P, Jana S (2017) A comprehensive physicochemical, thermal and spectroscopic characterization of zinc(II) chloride using X-ray diffraction, particle size distribution, differential scanning calorimetry, thermogravimetric analysis/ differential thermogravimetric analysis, ultraviolet-visible and Fourier transform-infrared spectroscopy. Int J Pharm Investig 7(1): 33-40.
32. Trivedi MK, Sethi KK, Panda P, Jana S (2017) Physicochemical, thermal and spectroscopic characterization of sodium selenate using XRD, PSD DSC, TGA/DTG, UV-vis, and FT-IR. Marmara Pharmaceutical Journal 21(2): 311-318

33. (1997) Desktop X-ray Diffractometer “MiniFlex+”. The Rigaku Journal 14(1): 29-36.

34.Zhang T, Paluch K, Scalabrino G, Frankish N, Healy AM, et al. (2015) Molecular structure studies of (1S,2S)-2-benzyl-2,3-dihydro-2-(1Hinden-2-yl)-1H-inden-1-ol. J Mol Struct 1083: 286-299.

35. Langford JI, Wilson AJC (1978) Scherrer after sixty years: A survey and some new results in the determination of crystallite size. J Appl Cryst 11: 102-113.

36. Mosharrof M, Nyström C (1995) The effect of particle size and shape on the surface specific dissolution rate of microsized practically insoluble drugs. Int J Pharm 122(1-2): 35- 47.

37. Zhao Z, Xie M, Li Y, Chen A, Li G, et al. (2015) Formation of curcumin nanoparticles via solution enhanced dispersion by supercritical $\mathrm{CO}_{2}$. Int J Nanomedicine 10: 3171-3181.

38. Inoue M, Hirasawa I (2013) The relationship between crystal morphology and XRD peak intensity on $\mathrm{CaSO}_{4} \cdot 2 \mathrm{H}_{2} \mathrm{O}$. J Crystal Growth 380: 169-175.

39. Brittain HG (2009) Polymorphism in pharmaceutical solids in drugs and pharmaceutical sciences. In: $2^{\text {nd }}$ Edn, Informa Healthcare USA, Inc., volume 192, New York, USA.

40. Raza K, Kumar P, Ratan S, Malik R, Arora S (2014) Polymorphism: the phenomenon affecting the performance of drugs. SOJ Pharm Pharm Sci 1(2): 10.

41. Sovizi MR, Hajimirsadeghi SS, Naderizadeh B (2009) Effect of particle size on thermal decomposition of nitrocellulose. J Hazard Mater 168(2-

3): 1134-1139.

For possible submissions Click below: 